\title{
Aberrant expression of interleukin-10 and activation-induced cytidine deaminase in B cells from patients with Behçet's disease
}

\author{
JEONG-YUN YOON $^{1 *}$, YEOJIN LEE $^{1 *}$, SEONG-LAN YU $^{1}$, HEE-KYUNG YOON ${ }^{2}$, \\ HA-YAN PARK ${ }^{2}$, CHUNG-IL JOUNG ${ }^{3}$, SEOK-RAE PARK ${ }^{*}$, MIHYE KWON $^{3}$ and JAEKU KANG ${ }^{1}$ \\ ${ }^{1}$ Myunggok Medical Research Institute; Departments of ${ }^{2}$ Microbiology and ${ }^{3}$ Internal Medicine, \\ College of Medicine, Konyang University, Daejeon 35365, Republic of Korea
}

Received July 4, 2017; Accepted September 19, 2017

DOI: 10.3892/br.2017.996

\begin{abstract}
Despite extensive studies, the pathogenesis of Behçet's disease (BD) remains unclear. In particular, the roles of $\mathrm{B}$ cells in patients with BD have not been elucidated. Activation-induced cytidine deaminase (AID) is a critical enzyme for immunoglobulin (Ig) heavy chain class switching and somatic hypermutation in B cells and the abnormal expression of AID in various immune conditions has previously been studied. B10 cells, an interleukin (IL)-10-secreting subset of regulatory $\mathrm{B}$ cells, function to downregulate inflammation and autoimmunity. Thus, in the present study, the relevance of $\mathrm{B}$ cells in patients with BD was investigated. The plasma levels of IL-10 and IgA and the proportions of cluster of differentiation (CD) $43^{+} \mathrm{B}$ cells, excluding naïve $\mathrm{B}$ cells, were measured
\end{abstract}

Correspondence to: Professor Mihye Kwon, Department of Internal Medicine, College of Medicine, Konyang University, 158 Gwanjeodong-Ro, Seo-gu, Daejeon 35365, Republic of Korea E-mail: mhkwon@kyuh.ac.kr

Professor Jaeku Kang, Myunggok Medical Research Institute, College of Medicine, Konyang University, 158 Gwanjeodong-ro, Seo-gu, Daejeon 35365, Republic of Korea

E-mail: jaeku@konyang.ac.kr

*Contributed equally

Abbreviations: AID, activation-induced cytidine deaminase; $\mathrm{BD}$, Behçet's disease; Bregs, regulatory $\mathrm{B}$ cells; $\mathrm{CD}$, cluster of differentiation; CSR, class switch recombination; DEPC, diethylpyrocarbonate; ELISA, enzyme-linked immunosorbent assay; FITC, fluorescein isothiocyanate; FOB, follicular B cells; HCs, healthy controls; Ig, immunoglobulin; IL, interleukin; ILB, innate-like B; MACS, magnetic-activated cell sorting; MZB, marginal zone B; MRS, Murphy Roths Large; PBMCs, peripheral blood mononuclear cells; PBS, phosphate-buffered saline; RT-qPCR, reverse transcription-quantitative polymerase chain reaction; SHM, somatic hypermutation; SLE, systemic lupus erythematosus

Key words: Behçet's disease, B cells, activation-induced cytidine deaminase, interleukin-10, cluster of differentiation 43 in 16 patients with BD and 16 age- and sex-matched healthy controls (HCs). Additionally, the mRNA levels of IL-10 and AID were assessed in B cells from fresh peripheral blood samples of the BD patients and HCs. The plasma level of IL-10 in patients with BD did not differ significantly from that in HCs. Similarly, there was no significant difference in the plasma level of IgA, although a slight increase was observed in patients with BD compared with that in HCs. There were no differences in $\mathrm{CD} 43^{+} \mathrm{CD} 19^{+} \mathrm{B}$ cell numbers between patients with $\mathrm{BD}$ and HCs. However, IL-10 mRNA levels were significantly reduced $(\mathrm{P}<0.05)$, while AID mRNA levels were significantly increased $(\mathrm{P}<0.01)$ in the $\mathrm{B}$ cells of patients with $\mathrm{BD}$ compared with those in HCs. These results provide insight into the role of $\mathrm{B}$ cells in patients with BD.

\section{Introduction}

Behçet's disease (BD) is a systemic auto-inflammatory disorder principally characterized by recurrent oral aphthous ulcers, genital ulcers and ocular inflammation. BD also affects numerous other organs involved in the vascular, articular, gastrointestinal, pulmonary, and central nervous systems (1). As the prevalence of $\mathrm{BD}$ is high in certain regions of the world, including the Mediterranean, Middle East, Turkey and East Asia (2), previous studies have attempted to identify the etiopathogenic mechanisms underlying BD $(1,2)$; however, the causes and pathogenesis remain unclear.

B lymphocytes serve various functions, by acting as antigen-presenting cells to activate cluster of differentiation (CD) $4^{+} \mathrm{T}$ cells, by providing costimulatory molecules and cytokines, and by producing antibodies within the humoral immune system (3). B cells are also considered to serve a critical role in the pathogenesis of BD (4-6). Patients with active $\mathrm{BD}$ have been reported to exhibit elevated numbers of immunoglobulin (Ig)-secreting B cells, which are representative of fully differentiated B cells in vivo (4). Increased levels of activated and memory B cell subsets also suggests that alterations in B cell function may be involved in the development of BD (5). The role of B cell activating factor in signaling in B cells may contribute to B cell abnormalities and the development of skin lesions in patients with BD (6). Although studies have also evaluated the roles of $\mathrm{T}$ cells in $\mathrm{BD}$ (7-9), numerous other reports have continued 
to emerge regarding the contributions of abnormalities in B cell-associated factors, including CD43 (10-13), activation-induced cytidine deaminase (AID) (14-19), and interleukin (IL)-10 (20-26), to the progression of autoimmune disease.

CD43, also known as leukosialin or sialophorin, is a cell surface glycoprotein that is considered to be involved in the modulation of apoptosis, cell differentiation, immune homeostasis, cell adhesion, anti-adhesion and signal transduction (10). CD43 antigen is expressed on the majority of leukocytes, and in particular, is expressed on activated B and plasma cells, though not on resting (naïve) $\mathrm{B}$ cells. Abnormal expression of CD43 has been reported in a number of autoimmune pathologies, including systemic lupus erythematosus (SLE), Wiskott-Aldrich syndrome and human immunodeficiency virus infection (11-13).

From the perspective of humoral immunity, AID is proposed to be an important mechanistic factor that influences B cell function (14). AID deaminates target cytidines (C) to uracil's $(\mathrm{U})$ in the Ig-encoding region and triggers $\mathrm{U}-\mathrm{G}$ mismatches; through this mechanism, AID initiates Ig somatic hypermutation (SHM) and class switch recombination (CSR) $(14,15)$, resulting in the affinity maturation of antibodies and production of different Ig classes against pathogenic antigens (15). Thus, changes in AID expression have been associated with the severity of autoimmune diseases, including lupus nephritis and rheumatoid arthritis in mouse models (16-19).

Among the various subsets of B cells, some specific types negatively regulate the cellular immune response and inflammation (20). In particular, IL-10-producing subsets of regulatory $\mathrm{B}$ cells (BREGS), known as B10 cells, are now considered to serve major functions in the downregulation of autoimmunity, inflammation, and innate and adaptive immune responses, and are amongst the most intensively studied BREG subsets (21-23). IL-10 is an anti-inflammatory cytokine that is involved in the development and maintenance of immune tolerance and homeostasis (24), and suppresses proinflammatory cytokine production and antigen presentation (25). B10 cells not only limit inflammation and immune responses through the production of IL-10, but also facilitate the clearance of antigens by producing antigen-specific antibodies during the humoral immune response (26).

Accordingly, in the present study, the role of B cells in the pathogenesis of BD was investigated. In particular, the phenotypic proportions of B cells were assessed to determine their effects of the autoimmune system, and the expression of AID in B cells from patients with BD was evaluated for the first time in vivo. Additionally, the expression and plasma concentration of IL-10 were measured to provide insight into the effects of IL-10 and the roles of B10 cells in $\mathrm{BD}$

\section{Materials and methods}

Patients and healthy controls (HCs). A total of 16 Korean patients with $\mathrm{BD}$ (11 women and 5 men; mean age, 50.06 \pm 9.43 ) and 16 age- and sex-matched HCs were recruited from Konyang University Hospital (Daejeon, Republic of Korea). All participants provided informed consent for participation in the study. All patients with BD met the International Study Group Classification Criteria for BD (27) and received outpatient treatment. The clinical manifestations of the patients are presented in Table I. HCs were identified as having no history of autoimmune disease or other health problems following blood sample collection. The present study was approved by the Institutional Review Board of Konyang University Hospital (approval no.: KYUH 2016-12-015-002).

Plasma and cell separation. Peripheral blood ( 8 $\mathrm{ml})$ was obtained from each patient and $\mathrm{HC}$ by venipuncture using plastic blood collection tubes containing lithium heparin (BD Biosciences, San Jose, CA, USA). The samples were treated to separate $\mathrm{B}$ cells within $1 \mathrm{~h}$ at room temperature. An equivalent volume of phosphate-buffered saline (PBS) was added to the fresh blood samples, the samples were centrifuged for $15 \mathrm{~min}$ at $500 \mathrm{x} \mathrm{g}$ at room temperature, and the plasma supernatant was collected. The heparinized-plasma was then stored at $-70^{\circ} \mathrm{C}$ until analysis by enzyme-linked immunosorbent assay (ELISA). After removing the remaining supernatant, corpuscles below the plasma were used to create a layer of peripheral blood mononuclear cells (PBMCs) by Histopaque density-gradient centrifugation (Sigma-Aldrich; Merck KGaA, Darmstadt, Germany) as previously described (28). The samples were then washed twice with Hank's balanced salt solution (Welgene, Inc., Daegu, Korea), and the acquired PBMCs were incubated for 30 min with CD19 microbeads (20 $\mu \mathrm{l}$ per $1 \times 10^{7}$ cells; Miltenyi Biotec GmbH., Bergisch Gladbach, Germany) on ice. As CD19 is only expressed on B cells (20), magnetic-activated cell sorting (MACS) allowed us to positively select B cells by flow cytometric analysis using a FACS Calibur flow cytometer (BD Biosciences, San Jose, CA, USA) (29).

The lymphocyte and B cell numbers in the blood samples were evaluated at two time points: Immediately after layering of the PBMCs, and following the isolation of B cells by MACS sorting. Two independent researchers counted the number of cells twice using an inverted fluorescence microscope (CKX41; Olympus Corp., Tokyo, Japan).

ELISA. The frozen plasma samples were used to measure the plasma levels of IL-10 and IgA. ELISA was performed with commercial ELISA kits [IgA human simplestep ELISA kit (cat. no. ab196263; Abcam, Cambridge, UK) and high sensitivity human IL-10 ELISA kit (cat. no. D1000B, R\&D Systems Inc., Minneapolis, MN, USA)] according to the manufacturer's instructions.

Flow cytometry analysis. Suspended B cells sorted using CD19 microbeads were washed with MACS buffer (Miltenyi Biotec GmbH, Bergisch Gladbach, Germany) and then incubated with anti-human CD19-phycoerythrin (25-0199) and anti-human CD43-fluorescein isothiocyanate (FITC; 11-0439) antibodies (each $0.25 \mu \mathrm{g} / 5 \mu \mathrm{l}$; Affeymetrix; Thermo Fisher Scientific Inc., Waltham, MA, USA) for $30 \mathrm{~min}$ on ice. After washing twice with PBS, the cells were fixed with $1 \%$ paraformaldehyde at $4^{\circ} \mathrm{C}$ until use. The cells were analyzed with the FACSCalibur cytometer using CellQuest software, and the data were confirmed with FlowJo V10 (Tree Star, Inc., Ashland, OR, USA). 
Table I. Clinical manifestations of patients with Behçet's disease.

\begin{tabular}{|c|c|c|c|c|c|c|c|c|c|c|}
\hline Case & $\begin{array}{l}\text { Sex/age } \\
\text { (years) }\end{array}$ & $\begin{array}{l}\text { Oral } \\
\text { ulcer }\end{array}$ & $\begin{array}{l}\text { Genital } \\
\text { ulcers }\end{array}$ & $\begin{array}{l}\text { Skin } \\
\text { lesions }\end{array}$ & $\begin{array}{l}\text { Eye } \\
\text { lesions }\end{array}$ & Thrombosis & Arthritis & Vasculitis & $\begin{array}{c}\text { ESR } \\
(\mathrm{mm} / \mathrm{h})\end{array}$ & $\begin{array}{c}\mathrm{CRP} \\
(\mathrm{mg} / \mathrm{l})\end{array}$ \\
\hline 1 & $\mathrm{~F} / 57$ & AU/DU/Mul/PL & $\mathrm{Y}$ & $\mathrm{EN} / \mathrm{PF}$ & Uveitis & $\mathrm{Y}$ & $\mathrm{Y}$ & $\mathrm{Y}$ & 11 & 0.2 \\
\hline $2^{\mathrm{a}}$ & $\mathrm{F} / 55$ & AU/DU/Mul/PL & $\mathrm{Y}$ & EN & $\begin{array}{l}\text { Uveitis, } \\
\text { conjunctivitis }\end{array}$ & $\mathrm{N}$ & $\mathrm{Y}$ & $\mathrm{Y}$ & 68 & 3.0 \\
\hline $3^{\mathrm{a}}$ & $\mathrm{M} / 52$ & $\mathrm{AU}$ & $\mathrm{Y}$ & EN & Conjunctivitis & $\mathrm{N}$ & $\mathrm{Y}$ & $\mathrm{Y}$ & 15 & 0.1 \\
\hline $4^{\mathrm{a}}$ & $\mathrm{M} / 25$ & AU/Mul & Y & EN & Uveitis & $\mathrm{N}$ & $\mathrm{N}$ & $\mathrm{Y}$ & 16 & 0.2 \\
\hline 5 & $\mathrm{~F} / 50$ & AU/Mul & $\mathrm{N}$ & EN & - & $\mathrm{N}$ & $\mathrm{N}$ & $\mathrm{Y}$ & 16 & 0.1 \\
\hline 6 & $\mathrm{~F} / 47$ & AU/Mul & Y & EN & Conjunctivitis & $\mathrm{N}$ & $\mathrm{Y}$ & $\mathrm{N}$ & 29 & 0.1 \\
\hline $7^{\mathrm{a}}$ & $\mathrm{M} / 43$ & $\mathrm{DU} / \mathrm{S}$ & $\mathrm{N}$ & $\mathrm{EN}$ & Uveitis & $\mathrm{N}$ & $\mathrm{N}$ & $\mathrm{N}$ & 5 & 0.1 \\
\hline 8 & $\mathrm{~F} / 61$ & AU/DU/Mul & $\mathrm{Y}$ & EN & - & $\mathrm{N}$ & $\mathrm{N}$ & $\mathrm{Y}$ & 15 & 0.3 \\
\hline 9 & $\mathrm{M} / 48$ & DU/ & Y & EN & - & $\mathrm{N}$ & $\mathrm{N}$ & $\mathrm{N}$ & 7 & 0.1 \\
\hline 10 & $\mathrm{M} / 53$ & AU/DU/Mul & $\mathrm{Y}$ & $\mathrm{EN} / \mathrm{PF}$ & Uveitis & $\mathrm{N}$ & $\mathrm{N}$ & $\mathrm{N}$ & 44 & 3.1 \\
\hline 11 & $\mathrm{~F} / 50$ & $\mathrm{AU}$ & $\mathrm{Y}$ & - & - & $\mathrm{N}$ & $\mathrm{N}$ & $\mathrm{N}$ & 12 & 0.1 \\
\hline 12 & $F / 38$ & $\mathrm{AU} / \mathrm{Mul} / \mathrm{PL}$ & $\mathrm{Y}$ & EN & Uveitis & $\mathrm{N}$ & $\mathrm{Y}$ & $\mathrm{N}$ & 45 & 4.0 \\
\hline 13 & $\mathrm{~F} / 49$ & DU & $\mathrm{Y}$ & $\mathrm{EN} / \mathrm{PF}$ & Uveitis & $\mathrm{N}$ & $\mathrm{N}$ & $\mathrm{N}$ & 9 & 0.9 \\
\hline 14 & $\mathrm{~F} / 59$ & $\mathrm{AU} / \mathrm{DU}$ & $\mathrm{Y}$ & EN & - & $\mathrm{N}$ & $\mathrm{N}$ & $\mathrm{N}$ & 24 & 0.1 \\
\hline 15 & $\mathrm{~F} / 55$ & AU/DU/Mul & $\mathrm{Y}$ & EN & - & $\mathrm{N}$ & $\mathrm{N}$ & $\mathrm{N}$ & 39 & 1.4 \\
\hline $16^{\mathrm{a}}$ & $\mathrm{F} / 38$ & AU/DU/Mul & $\mathrm{Y}$ & EN & $\begin{array}{l}\text { Conjunctivitis, } \\
\text { optic neuritis }\end{array}$ & $\mathrm{N}$ & $\mathrm{N}$ & $\mathrm{N}$ & 10 & 2.7 \\
\hline
\end{tabular}

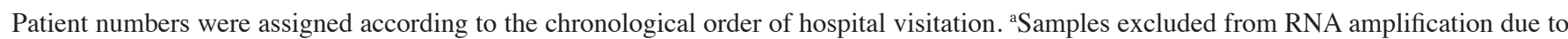
low RNA quality. AU, aphthae ulcer; DU, deep ulcer; Mul, multiple; S, single; PL, posterior location; EN, erythema nodosum; PF, pseudofolliculitis; ESR, erythrocyte sedimentation rate; CRP, C-reactive protein; Y, present; N, not present; M, male; F, female.

$R N A$ amplification and reverse transcription-quantitative polymerase chain reaction $(R T-q P C R)$. Total RNA was extracted from B cells using an RNAqueous-micro total RNA isolation kit (Invitrogen; Thermo Fisher Scientific, Inc.). The concentration and quality of the total RNA were assessed using an Optizen 3220 UV spectrophotometer (Rose Scientific Ltd., Edmonton, Canada). However, the quantities of isolated total RNA were inadequate, and thus mRNA was amplified after synthesizing cDNA from RNA samples with qualities of $>1.6$ (absorbance 260/280) using a QuantiTect whole transcriptome kit (Qiagen, Inc., Valencia, CA, USA) to obtain a concentration of $100 \mathrm{ng} / \mu \mathrm{l}$ complementary DNA according to the manufacturer's instructions. For subsequent use, the amplified cDNA was diluted to $2 \mathrm{ng} / \mu \mathrm{l}$ in diethylpyrocarbonate (DEPC)-treated distilled $\mathrm{H}_{2} \mathrm{O}$ (Sigma-Aldrich; Merck KGaA).qPCR was performed in a final volume of $20 \mu \mathrm{l}$ containing $2 \mu \mathrm{l}$ diluted cDNA, $0.5 \mu \mathrm{l}$ of $100 \mathrm{pmol} / \mu \mathrm{l}$ of each forward and reverse primer, $10 \mu 1$ buffer (iQ SYBR-Green Supermix; Bio-Rad Laboratories, Inc., Hercules, CA, USA) and $7 \mu \mathrm{l}$ DEPC-treated distilled $\mathrm{H}_{2} \mathrm{O}$ using a CFX96 touch real-time PCR detection 29 system (Bio-Rad Laboratories, Inc.). The primers used in the study were as follows: IL-10, forward, 5'-ACCTGGGTTGCCAAGCCTT-3' and reverse, 5'-ATCGAT GACAGCGCCGTAG-3'; AID, forward, 5'-CCTCTTGATGA ACCGGAGGAA-3' and reverse, 5'-AGCACTGTCACGCCTC TTCACT-3'; and glyceraldehyde 3-phosphate dehydrogenase (GAPDH), forward, 5'-ACAGTCAGCCGCATCTTCTT-3' and reverse, 5'-ACGACCAAATCCGTTGACTC-3'. The qPCR conditions to amplify AID, IL-10 and GAPDH were as follows:
Initial denaturation at $95^{\circ} \mathrm{C}$ for 3 min followed by 50 cycles of denaturation at $95^{\circ} \mathrm{C}$ for $10 \mathrm{sec}$, annealing for $10 \mathrm{sec}$ at an appropriate temperature $\left(56^{\circ} \mathrm{C}\right.$ for IL-10 and GAPDH, $60^{\circ} \mathrm{C}$ for AID), and extension at $72^{\circ} \mathrm{C}$ for $10 \mathrm{sec}$. The targeted mRNA expression levels were quantified following normalization to the expression of GAPDH using the comparative threshold cycle $(\Delta \Delta \mathrm{Cq})$ method (30).

Statistical analysis. The data are presented as mean \pm standard error of the mean unless otherwise stated. The significance of differences was determined by two-tailed paired Student's $\mathrm{t}$ tests, and differences with $\mathrm{P}<0.05$ were considered to indicate a statistically significant difference. All statistical analyses were performed with Excel 2013 (Microsoft Corp., Redmond, WA, USA).

\section{Results}

Plasma concentrations of IL-10 and IgA. IL-10 is an anti-inflammatory cytokine that inhibits the production of proinflammatory cytokines and serves a role in the development and maintenance of immune tolerance and homeostasis $(24,25)$. IgA is present at high levels at mucosal sites and is responsible for mucosal immunity (31); however, a number of patients with BD have been documented to have IgA nephropathy (32). Therefore, the present study measured the plasma levels of IL-10 and IgA by ELISA. The results indicated that the levels of IL-10 between patients with BD and HCs did not markedly differ $(3.71 \pm 0.29$ vs. $3.64 \pm 0.02$, 
Table II. Comparisons of B cell and lymphocyte counts between patients with BD and HCs.

\begin{tabular}{lccc}
\hline Cell type & BD & HC & P-value $^{\mathrm{a}}$ \\
\hline Lymphocytes $\left(\times 10^{5} / \mathrm{ml}\right)$ & $7.02 \pm 0.85$ & $7.76 \pm 0.72$ & 0.51 \\
B cells $\left(\times 10^{4} / \mathrm{ml}\right)$ & $7.24 \pm 1.52$ & $9.60 \pm 1.07$ & 0.21 \\
B cells/lymphocytes $(\%)$ & $9.43 \pm 1.34$ & $12.61 \pm 1.15$ & 0.08
\end{tabular}

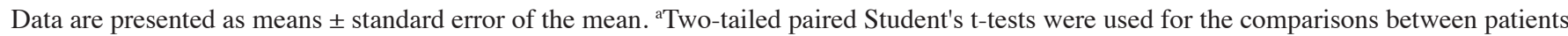
with BD and HCs. BD, Behçet disease; HC, healthy control.

A

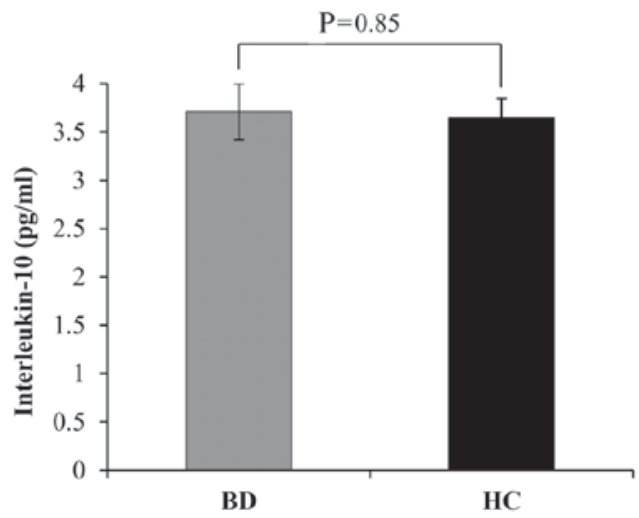

B

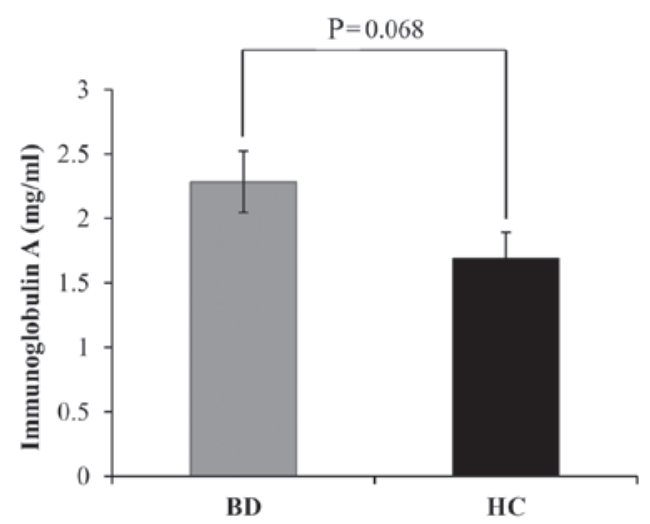

Figure 1. Plasma concentrations of IL-10 and IgA. The plasma levels of (A) IL-10 and (B) IgA were determined using ELISA for samples from patients with $\mathrm{BD}(\mathrm{n}=16)$ and age- and sex-matched HCs $(\mathrm{n}=16)$. BD, Behçet's disease; HCs, healthy controls; IL-10, interleukin-10; IgA, immunoglobulin A.

respectively; $\mathrm{P}=0.85$; Fig. $1 \mathrm{~A})$. Meanwhile, IgA levels were notably increased in patients with BD compared with HCs; however, the difference was not significant $(2.28 \pm 0.24$ vs. $1.69 \pm 0.20$, respectively; $P=0.068$; Fig. $1 B$ ).

$\mathrm{CD} 3^{+} \mathrm{CD} 19^{+} \mathrm{B}$ cell count is indistinguishable between patients with $B D$ and $H C s$. Lymphocyte and B cell numbers were slightly reduced in the PBMC populations of patients with BD compared with those in $\mathrm{HCs}$, and the percentage of $\mathrm{B}$ cells to lymphocytes was markedly lower in patients with $\mathrm{BD}$; however, the differences were not significant (Table II). CD19 ${ }^{+} \mathrm{B}$ cells were isolated to $\sim 97 \%$ purity (Fig. 2A) from the human PBMCs and anti-human CD43-FITC antibodies were used to determine changes in the activated $\left(\mathrm{CD} 43^{+} \mathrm{CD} 19^{+}\right)(33) \mathrm{B}$ cell population by flow cytometry analysis. Despite the reduction in the $\mathrm{B}$ cell percentage, the number of $\mathrm{CD} 43^{+} \mathrm{CD} 19^{+} \mathrm{B}$ cells in patients with BD did not differ significantly compared with that in HCs (2.41 \pm 0.57 vs. $2.29 \pm 0.31$, respectively; $\mathrm{P}=0.86$; Fig. $2 \mathrm{~B})$. This result corresponds to a previous report that observed no marked alteration in the CD $43^{+} \mathrm{B}$ cell component of patients with SLE compared with healthy donors (34).

Expression of IL-10 and AID mRNA in B cells. To further investigate abnormalities that may affect the etiopathology of $\mathrm{BD}$, the expression of IL-10 and AID mRNA was evaluated. The results indicated that the mRNA levels of IL-10 were significantly downregulated in patients with BD compared with those in $\mathrm{HCs}(0.49 \pm 0.12$ vs. $1.08 \pm 0.26$, respectively;
$\mathrm{P}=0.03$; Fig. 3A). Meanwhile, the levels of AID mRNA were significantly increased in patients with BD compared with those in $\mathrm{HCs}(10.27 \pm 2.72$ vs. $1.04 \pm 0.12$, respectively; $\mathrm{P}=0.003$; Fig. 3B). These results were consistent with previous studies suggesting that high expression of AID triggers autoimmune disease in lupus-prone mice (18) and that abnormal AID expression contributes to autoimmune diseases (35).

\section{Discussion}

The objective of the present study was to investigate changes in B cells in patients with BD. Specifically, phenotypic analysis was conducted by comparing CD $43^{+}$populations among patients with BD and HCs. Although the number of $\mathrm{CD} 43^{+} \mathrm{CD} 19^{+} \mathrm{B}$ cells did not differ between patients with BD and $\mathrm{HCs}$, it was observed, to the best of our knowledge for the first time, that the expression of IL-10 mRNA in B cells was significantly decreased in patients with BD compared with HCs. Furthermore, AID mRNA levels in B cells were increased by $\sim 10$-fold in patients with $\mathrm{BD}$ compared with those in HCs.

To date, studies of AID, as a factor involved in immunity, have demonstrated that this protein can induce autoantibody production (16-19). A study by Hsu et al (16) reported that BXD2 mice, presenting with age-related development and progression of arthritis, glomerulonephritis and high immune complex titers, exhibited significant alterations in autoantibody production and AID expression in the germinal center when compared with wild-type mice. Murphy roths large (MRL) 
A

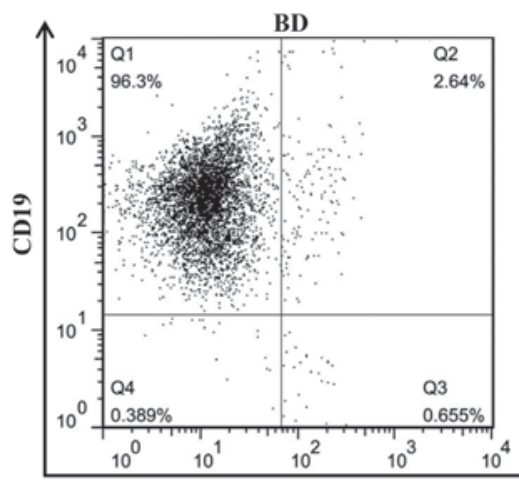

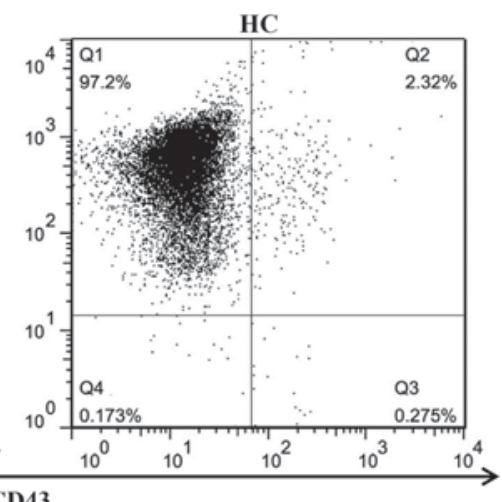

CD43

$\mathrm{B}$

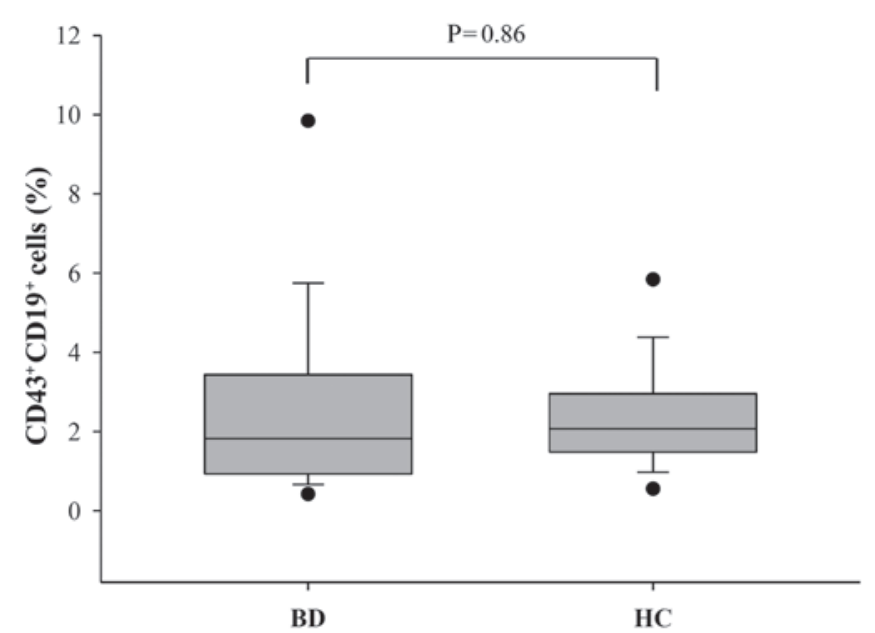

Figure 2. Frequencies of $\mathrm{CD} 43^{+} \mathrm{CD} 19^{+}$cells in BD patients and HCs. CD19+ cells were purified from the peripheral blood mononuclear cell populations of patients with $\mathrm{BD}(\mathrm{n}=16)$ and $\mathrm{HCs}(\mathrm{n}=16)$. (A) Representative histograms of the $\mathrm{CD} 43^{+}$expression rate in $\mathrm{CD} 19^{+} \mathrm{B}$ cells, as determined by FlowJo analysis (B) $\mathrm{CD}_{4} 3^{+} \mathrm{CD} 19^{+}$cell percentage. The box plots represent the medians, interquartile ranges, standard errors and highest/lowest values. BD, Behçet's disease; HCs, healthy controls; CD, cluster of differentiation.

A

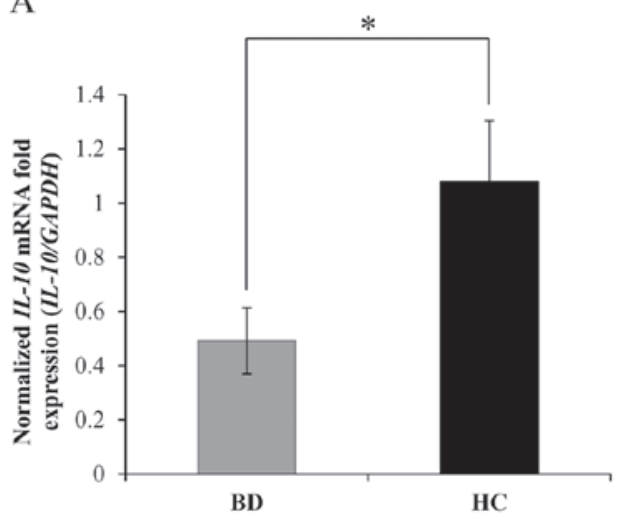

B

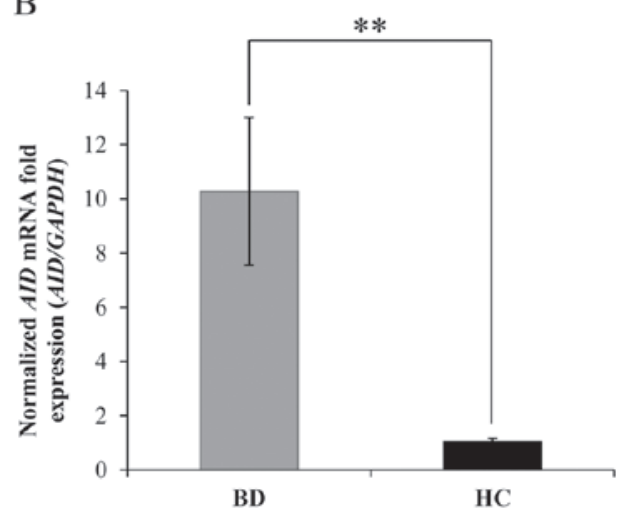

Figure 3. Changes in the expression of IL-10 and AID mRNA in CD19+ B cells. RNAs were isolated from purified CD19+ B cells of patients with BD and HCs ( $n=11$ per group; 5 patient samples were excluded from RNA amplification due to low RNA quality), and the levels of (A) IL-10 and (B) AID mRNA were measured using RT-qPCR. All data are represented as a fold-change using GAPDH as a control. ${ }^{*} \mathrm{P}<0.05$, ${ }^{* *} \mathrm{P}<0.01$. AID, activation-induced cytidine deaminase; IL-10, interleukin-10; BD, Behçet's disease; HCs, healthy controls; RT-qPCR, reverse transcription-quantitative polymerase chain reaction.

mice, which present SLE-like symptoms, also exhibit increased AID expression, and hyperactivity of SHM and CSR when focusing on heavy mutations in the Ig locus (18). Additionally, in AID-knockdown and AID-knockout MRL mice, lupus nephritis, as a main condition triggered by autoantibodies, was alleviated compared with AID wild-type MRL mice $(17,19)$.
Furthermore, AID may account for the antibody-independent role of B cells in T cell activation and autoimmunity (36). In the present study, it was observed that AID mRNA expression was markedly increased in patients with BD patient compared with HCs. Although the majority of previous studies have been performed in mice, the indicated effects of autoantibodies 
may also be relevant in the pathogenesis of $\mathrm{BD}$ in humans However, the specific underlying mechanisms remain unclear, and additional studies are required to determine the exact relationship between AID and BD. Specifically, to elucidate the effect of aberrant AID expression on Ig CSR and SHM in $\mathrm{B}$ cells in $\mathrm{BD}$, the expression patterns and functional roles of AID splicing variants should be examined in BD B cells, as AID splicing variants have been indicated to serve various functions in Ig CSR and SHM (37).

BREGS are involved in immunomodulation and suppression of the immune response through a range of mechanisms. The roles of BREGS have been studied in mouse models of autoimmune diseases including SLE (38) and experimental autoimmune encephalomyelitis (21). However, there is no clear understanding of the characteristics of BREGS (39). Three mature $B$ cell subsets have been identified in mice [B1 cells, follicular B (FOB) cells, marginal zone B (MZB) cells]; these subsets have different characteristics regarding their phenotypes and functional activities (40). In particular, FOB cells, also known as adaptive B cells, and MZB cells belong to a subset of innate-like B (ILB) cells termed B2 cells. These B2 cells contribute to the adaptive immune response and mediate humoral immunity; they may also produce highaffinity antibodies and generate immunological memory (41). Human B1 cells are typically considered as CD $43^{+} \mathrm{B}$ cells, while B2 cells may be regarded as CD43- B cells (34). Furthermore, CD43- IL-10-producing ILB cells have been identified to have BREG activity in immune responses during chlamydia infection (42). In the present study, IL-10 mRNA expression was reduced in the $\mathrm{B}$ cells of patients with $\mathrm{BD}$, suggesting that the percentage of CD43- IL-10-producing B cells may be reduced in $\mathrm{BD}$, as these cells have more potential than CD43+ IL-10producing $B$ cells to affect the immune system. However, only the whole $\mathrm{CD}^{-} 3^{-} \mathrm{B}$ cell was distinguished from the whole $\mathrm{CD} 43^{+} \mathrm{B}$ cell proportion; therefore, further studies are necessary to clarify the involvement of IL-10-producing subtypes in BD. Meanwhile, in contrast to IL-10 mRNA levels, plasma IL-10 levels were not altered. This result may be explained by the observation that $\mathrm{T}$ cells and neutrophils also produce IL-10 $(43,44)$. In addition, the change in IL-10 level may not be reflected in the plasma as the proportion of total B cells in the peripheral blood is relatively low $(\sim 10 \%)$ (45).

There were a number of limitations to the present study. Firstly, the patients were not grouped according to the status of BD (active vs. inactive). Due to the experimental methods used in the study, fresh blood samples were required from patients, and blood was drawn from patients immediately following their visit to the hospital. However, it was not possible to request that patients visit the hospital specifically when they had symptoms. Thus, the majority of the patients were evaluated during the inactive disease period, and only three patients presented with active BD during evaluation. Secondly, all the patients with BD were treated with medication at the time of blood sampling. This may have affected the results of serum cytokine analysis and RT-qPCR. Therefore, further studies are required with improved control of patient treatment and blood sample collection in order to obtain results of higher accuracy.

In conclusion, the present study described the concentrations of IL-10 and IgA in plasma, the number of
$\mathrm{CD} 43^{+} / \mathrm{CD} 43^{-} \mathrm{B}$ cells and the mRNA levels of IL-10 and AID in B cells from fresh peripheral blood samples of patients with $\mathrm{BD}$ and matched HCs. The present findings indicated, to the best of our knowledge for the first time, that AID mRNA was upregulated in patients with BD. These data may be a starting point for examining the mechanisms and influence of AID in $\mathrm{BD}$ in further studies. Correlations between disease severity and AID expression should also be evaluated, which may implicate the applications of AID in the diagnosis or treatment of BD. Furthermore, based on the present results that IL-10 mRNA was downregulated in B cells in vivo, future studies should be performed to analyze B10 cells, which downregulate immune responses, to elucidate the immunological mechanisms involved in BD.

\section{Acknowledgements}

The current study was supported by the National Research Foundation of Korea funded by the Korean Government (grant nos. NRF-2015R1D1A3A01019948 and NRF-2017R1C1B2008199).

\section{References}

1. Kural-Seyahi E, Fresko I, Seyahi N, Ozyazgan Y, Mat C, Hamuryudan V, Yurdakul S and Yazici H: The long-term mortality and morbidity of Behcet syndrome: A 2-decade outcome survey of 387 patients followed at a dedicated center. Medicine (Baltimore) 82: 60-76, 2003.

2. Khairallah M, Accorinti M, Muccioli C, Kahloun R and Kempen JH: Epidemiology of Behçet disease. Ocul Immunol Inflamm 20: 324-335, 2012.

3. LeBien TW and Tedder TF: B lymphocytes: How they develop and function. Blood 112: 1570-1580, 2008.

4. Suzuki N, Sakane T, Ueda Y and Tsunematsu T: Abnormal B cell function in patients with Behçet's disease. Arthritis Rheum 29: 212-219, 1986.

5. Ekşioglu-Demiralp E, Kibaroglu A, Direskeneli H, Yavuz S, Karsli F, Yurdakul S, Yazici H and Akoglu T: Phenotypic characteristics of B cells in Behçet's disease: Increased activity in B cell subsets. J Rheumatol 26: 826-832, 1999.

6. Hamzaoui K, Houman H, Ben Dhifallah I, Kamoun M and Hamzaoui A: Serum BAFF levels and skin mRNA expression in patients with Behçet's disease. Clin Exp Rheumatol 26): 64-71, 2008.

7. Imamura Y, Kurokawa MS, Yoshikawa H, Nara K, Takada E, Masuda C, Tsukikawa S, Ozaki S, Matsuda T and Suzuki N: Involvement of Th1 cells and heat shock protein 60 in the pathogenesis of intestinal Behcet's disease. Clin Exp Immunol 139: 371-378, 2005.

8. Geri G, Terrier B, Rosenzwajg M, Wechsler B, Touzot M, Seilhean D, Tran TA, Bodaghi B, Musset L, Soumelis V, et al: Critical role of IL-21 in modulating TH17 and regulatory T cells in Behçet disease. J Allergy Clin Immunol 128: 655-664, 2011.

9. Hughes T, Ture-Ozdemir F, Alibaz-Oner F, Coit P, Direskeneli H and Sawalha AH: Epigenome-wide scan identifies a treatment-responsive pattern of altered DNA methylation among cytoskeletal remodeling genes in monocytes and CD4+ T cells from patients with Behçet's disease. Arthritis Rheumatol 66: 1648-1658, 2014.

10. Pedraza-Alva G and Rosenstein Y: CD43- One molecule, many tales to recount. Signal Transduct 7: 372-385, 2007.

11. Liang ZB, Zhang SF and Xu J: CD43 preliminary study of expression of CD43 antigen on lymphocytes of peripheral blood in patients with SLE. Zhonghua Pifuke Zazhi 31: 14-18, 1998.

12. Parkman R, Remold-O'Donnell E, Kenney DM, Perrine S and Rosen FS: Surface protein abnormalities in lymphocytes and platelets from patients with Wiskott-Aldrich syndrome. Lancet 2: 1387-1389, 1981.

13. Gallego MD, Aguado E, Kindelán JM, Peña J, Santamaría M and Molina IJ: Altered expression of CD43-hexasaccharide isoform on peripheral T lymphocytes from HIV-infected individuals. AIDS 15: 477-481, 2001. 
14. Park SR: Activation-induced cytidine deaminase in B cell immunity and cancer. Immune Netw 12: 230-239, 2012.

15. Nussenzweig MC and Alt FW: Antibody diversity: One enzyme to rule them all. Nat Med 10: 1304-1305, 2004

16. Hsu HC, Wu Y, Yang P, Wu Q, Job G, Chen J, Wang J, Accavitti-Loper MAV, Grizzle WE, Carter $\mathrm{RH}$, et al: Overexpression of activation-induced cytidine deaminase in $\mathrm{B}$ cells is associated with production of highly pathogenic autoantibodies. J Immunol 178: 5357-5365, 2007.

17. Jiang C, Foley J, Clayton N, Kissling G, Jokinen M, Herbert R and Diaz M: Abrogation of lupus nephritis in activationinduced deaminase-deficient MRL/lpr mice. J Immunol 178 7422-7431, 2007

18. Zan H, Zhang J, Ardeshna S, Xu Z, Park SR and Casali P: Lupus-prone MRL/faslpr/lpr mice display increased AID expression and extensive DNA lesions, comprising deletions and insertions, in the immunoglobulin locus: Concurrent upregulation of somatic hypermutation and class switch DNA recombination. Autoimmunity 42: 89-103, 2009.

19. Jiang C, Zhao ML and Diaz M: Activation-induced deaminase heterozygous MRL/lpr mice are delayed in the production of high-affinity pathogenic antibodies and in the development of lupus nephritis. Immunology 126: 102-113, 2009.

20. DiLillo DJ, Matsushita T and Tedder TF: B10 cells and regulatory B cells balance immune responses during inflammation, autoimmunity, and cancer. Ann N Y Acad Sci 1183: 38-57, 2010.

21. Matsushita T, Yanaba K, Bouaziz JD, Fujimoto $M$ and Tedder TF: Regulatory B cells inhibit EAE initiation in mice while other B cells promote disease progression. J Clin Invest 118: 3420-3430, 2008

22. Mauri $\mathrm{C}$ and Bosma A: Immune regulatory function of B cells. Annu Rev Immunol 30: 221-241, 2012.

23. Yanaba K, Bouaziz JD, Haas KM, Poe JC, Fujimoto M and Tedder TF: A regulatory B cell subset with a unique CD1dhi CD5+ phenotype controls $\mathrm{T}$ cell-dependent inflammatory responses. Immunity 28: 639-650, 2008.

24. Anderson AC, Reddy J, Nazareno R, Sobel RA, Nicholson LB and Kuchroo VK: IL-10 plays an important role in the homeostatic regulation of the autoreactive repertoire in naive mice. J Immunol 173: 828-834, 2004.

25. Moore KW, de Waal Malefyt R, Coffman RL and O'Garra A Interleukin-10 and the interleukin-10 receptor. Annu Rev Immunol 19: 683-765, 2001.

26. Maseda D, Smith SH, DiLillo DJ, Bryant JM, Candando KM, Weaver CT and Tedder TF: Regulatory B10 cells differentiate into antibody-secreting cells after transient IL-10 production in vivo. J Immunol 188: 1036-1048, 2012.

27. Weichsler B, Davatchi F, Mizushima Y, Hamza M, Dilsen N, Kansu E, Yazici H, Barnes CG, Chamberlain MA, James DG, et al; International Study Group for Behcet's Disease: Criteria for diagnosis of Behcet's disease. Lancet 335: 1078-1080, 1990.

28. Fuss IJ, Kanof ME, Smith PD, Zola H: Isolation of whole mononuclear cells from peripheral blood and cord blood. Curr Protoc Immunol 85:7.1.1-7.1.8,2009. https://doi.org/10.1002/0471142735. im0701s85.

29. Miltenyi S, Müller W, Weichel W and Radbruch A: High gradient magnetic cell separation with MACS. Cytometry 11: 231-238, 1990.

30. Livak KJ and Schmittgen TD: Analysis of relative gene expression data using real-time quantitative PCR and the 2(-Delta Delta C(T)) Method. Methods 25: 402-408, 2001.
31. Cho SB, Ahn KJ, Kim DH, Zheng Z, Cho S, Kang SW, Lee JH, Park YB, Lee KH and Bang D: Identification of HnRNP-A2/B1 as a target antigen of anti-endothelial cell IgA antibody in Behçet's disease. J Invest Dermatol 132: 601-608, 2012.

32. Altay M, Secilmis S, Unverdi S, Ceri M and Duranay M: Behcet's disease and IgA nephropathy. Rheumatol Int 32: 2227-2229, 2012.

33. Barclay A, Brown M, Alex Law SK, McKnight A, Tomlinson M and van der Merwe P: The Leukocyte Antigen Factsbook. Academic press, London, 1997.

34. Inui M, Hirota S, Hirano K, Fujii H, Sugahara-Tobinai A, Ishii T, Harigae $\mathrm{H}$ and Takai T: Human CD43+ B cells are closely related not only to memory B cells phenotypically but also to plasmablasts developmentally in healthy individuals. Int Immunol 27: 345-355, 2015.

35. Hase K, Takahashi D, Ebisawa M, Kawano S, Itoh K and Ohno H: Activation-induced cytidine deaminase deficiency causes organ-specific autoimmune disease. PLoS One 3: e3033, 2008.

36. Jiang C, Zhao ML, Waters KM and Diaz M: Activation-induced deaminase contributes to the antibody-independent role of $\mathrm{B}$ cells in the development of autoimmunity. Autoimmunity 45: 440-448, 2012

37. Wu X, Darce JR, Chang SK, Nowakowski GS and Jelinek DF: Alternative splicing regulates activation-induced cytidine deaminase (AID): Implications for suppression of AID mutagenic activity in normal and malignant B cells. Blood 112: 4675-4682, 2008.

38. Douglas RS, Woo EY, Capocasale RJ, Tarshis AD, Nowell PC and Moore JS: Altered response to and production of TGF-beta by $B$ cells from autoimmune NZB mice. Cell Immunol 179: 126-137, 1997.

39. Vitale G, Mion F and Pucillo C: Regulatory B cells: Evidence, developmental origin and population diversity. Mol Immunol 48: $1-8,2010$

40. Rawlings DJ, Schwartz MA, Jackson SW and Meyer-Bahlburg A: Integration of B cell responses through Toll-like receptors and antigen receptors. Nat Rev Immunol 12: 282-294, 2012.

41. 41. Nadler LM, Stashenko P, Hardy R, van Agthoven A, Terhorst C and Schlossman SF: Characterization of a human B cell-specific antigen (B2) distinct from B1. J Immunol 126: 1941-1947, 1981.

42. Moore-Connors JM, Kim HS, Marshall JS, Stadnyk AW, Halperin SA and Wang J: CD43-, but not CD43+, IL-10-producing CD1dhiCD5+ B cells suppress type 1 immune responses during Chlamydia muridarum genital tract infection. Mucosal Immunol 8: 94-106, 2015.

43. Barrat FJ, Cua DJ, Boonstra A, Richards DF, Crain C, Savelkoul HF, de Waal-Malefyt R, Coffman RL, Hawrylowicz $\mathrm{CM}$ and $\mathrm{O}^{\prime}$ Garra $\mathrm{A}$ : In vitro generation of interleukin 10-producing regulatory $\mathrm{CD} 4(+) \mathrm{T}$ cells is induced by immunosuppressive drugs and inhibited by T helper type 1 (Th1)- and Th2-inducing cytokines. J Exp Med 195: 603-616, 2002.

44. Romani L, Mencacci A, Cenci E, Spaccapelo R, Del Sero G, Nicoletti I, Trinchieri G, Bistoni F and Puccetti P: Neutrophil production of IL-12 and IL-10 in candidiasis and efficacy of IL-12 therapy in neutropenic mice. J Immunol 158: 5349-5356, 1997.

45. Morbach H, Eichhorn EM, Liese JG and Girschick HJ: Reference values for B cell subpopulations from infancy to adulthood. Clin Exp Immunol 162: 271-279, 2010. 